Jurnal Perpustakaan Universitas Airlangga: Media Informasi dan Komunikasi Kepustakawanan https://e-journal.unair.ac.id/JPERPUS

\section{ANALYSIS OF SERVICES OF BINTANG KECIL COMMUNITY READING PARK IN BATU PALANO, WEST SUMATRA TOWARDS LIBRARY SERVICES IN FACING THE COVID-19 PANDEMIC}

\author{
ANALISIS LAYANAN KEGIATAN TAMAN BACA BINTANG \\ KECIL DI BATU PALANO SUMATERA BARAT TERHADAP \\ LAYANAN PERPUSTAKAAN DALAM MENGHADAPI \\ PANDEMI COVID-19
}

\section{Research Report} Penelitian

\author{
Ajri Rhaysa Maulina*, Sukaesih, Evi Nursanti Rukmana, Samson CMS \\ Program Studi Perpustakaan dan Sains Informasi, Universitas Padjadjaran, Bandung - Indonesia
}

\begin{abstract}
A B S T R A C T
The prolonged Covid-19 pandemic during 2020 made all activities blocked, delayed, and even stopped. The people of Batu Palano, Sungai Pua District, Agam Regency, West Sumatra, have also felt the impact of the Covid-19 pandemic by limiting their activities and direct contact with people (physical distancing). One of the restricted activities is online school learning for the kindergarten to college level. Online-based school learning does not allow all regions to access it every day. This problem also affects school children in Batu Palano. Most junior high school and elementary school children in Batu Palano do not have gadgets to carry out online learning. So that Bintang Kecil Reading Park in Batu Palano becomes an oasis for school children in accessing its collections to support their online learning activities. This study analyzes the relationship between community reading park Bintang Kecil and library services, whether they have the same services even though they have different titles, and how Bintang Kecil community reading park survives in the Covid-19 pandemic situation. Implementing the management of the Bintang Kecil Reading Park really implements the role of the librarian in serving the users in it. The establishment of the Bintang Kecil Reading Park in Batu Palano Village can be the first step to increase its collection so that in the future it can develop into a village library where not only school children have access to information, but can also provide collection sources. To other people in Batu Palano Village.
\end{abstract}

\section{NFO ARTICLE}

Received: Nopember 2020

Accepted: August 2021

Published: Nopember 2021

Correspondence:

Ajri Rhaysa Maulina

Email:

ajri19001@mail.unpad.ac.id

Keywords:

Community Reading

Gardens, Library Services,

Covid-19. 


\section{A B S T R A K}

Pandemi Covid-19 yang mengguncang dunia pada awal tahun 2020 telah memaksa perubahan hidup manusia. Manusia dipaksa menemukan formula baru dalam beraktivitas. Dalam masa pandemi Covid-19 ini, semua aktivitas harus tetap dijalankan dengan menaati aturan yang ketat. Perpustakaan harus mengikuti peraturan dalam memberikan layanan kepada pemustaka. Layanan referensi menjadi salah satu garda terdepan komunikasi antara perpustakaan dengan pemustaka. Di era pandemi ini, perpustakaan menghadapi tantangan yang sedemikian masif, maka perpustakaan tidak lagi dapat menunda dalam mengoptimalisasi layanan referensi. Metode penelitian dalam tulisan ini adalah kajian pustaka atau studi kepustakaan. Peneliti akan mengemukakan teori-teori tentang layanan referensi dikaitkan kondisi pandemi Covid-19 serta dalam bingkai kampus merdeka. Optimalisasi layanan referensi yang dapat dilakukan antara lain Mobile references service; Pendidikan jarak jauh bagi pemustaka; Ask librarian; Remote library; Research support; Video tutorial; New Flash / glance; Kolaborasi. Optimalisasi tersebut diharapkan dapat menjembatani kurangnya informasi pemustaka dalam melaksanakan program kampus merdeka.

\section{Kata Kunci:}

Taman Bacaan Masyarakat, Layanan Perpustakaan, Covid-19.

\section{PENDAHULUAN}

Pandemi Covid-19 yang sudah berkepanjangan selama hampir 10 bulan dari awal tahun 2020 memberikan efek yang sangat luar biasa dalam perkembangannya. Di samping kasus yang setiap hari terus melonjak, semua sektor bidang di kehidupan masyarakat juga terganggu mulai dari perusahaan raksasa maupun kegiatan kecil rintisan masyarakat juga terkena dampak dari pandemi Covid-19 ini. Hal ini membuat setiap sektor terus membuat perkembangan baru untuk menyesuaikan keadaan yang terjadi saat ini. Covid-19 seolaholah menuntut semua sektor untuk memanfaatkan segala kesempatan yang ada dalam keterbatasan untuk terus mencapai hasil yang maksimal. Himbauan keharusan kita untuk selalu membatasi kontak langsung dengan banyak orang dan melakukan segala aktivitas yang hanya boleh dilakukan di rumah, menjadikan kinerja setiap orang menjadi melambat bahkan berhenti sementara.

Masyarakat Batu Palano, Kecamatan Sungai Pua, Kabupaten Agam, Sumatera Barat, turut merasakan dampak pandemi Covid-19 ini dengan pembatasan aktivitas dan kontak langsung dengan orang banyak. Walaupun berada di kaki Gunung Marapi, masyarakat Batu Palano bukanlah pengecualian untuk pembatasan aktivitas dari pandemi Covid-19. Salah satu aktivitas yang dibatasi adalah dirumahkannya pembelajaran sekolah dari tingkat sekolah dasar hingga sekolah menengah atas. Pembelajaran sekolah berbasis daring tidak memungkinkan seluruh daerah bisa mengaksesnya setiap hari, masalah ini berimbas juga kepada anak-anak sekolah di Batu Palano. Untuk anak-anak sekolah menengah atas mungkin saja sudah sebagian besar memiliki gadget yang mumpuni untuk melaksanakan kegiatan pembelajaran secara daring. Namun untuk anak-anak sekolah menengah pertama dan sekolah dasar di Batu Palano justru sebaliknya, sebagian besar tidak memiliki gadget untuk melaksanakan belajar daring. Orang tua mereka yang mayoritas setiap hari bertani dan beternak, belum bisa menjadi pendamping mereka dalam belajar daring, menjadi kesedihan yang dihadapi anakanak sekolah pada tingkat ini. Sehingga kehadiran Taman Baca Bintang Kecil di Batu Palano menjadi sebuah oase bagi anak-anak sekolah dasar dan sekolah menengah pertama dalam mengakses koleksi-koleksinya untuk menunjang kegiatan belajar daring mereka.

Taman Baca Bintang Kecil yang hadir sebelum adanya pandemi Covid-19, berusaha tetap menjalankan amanahnya dalam melayani penggunanya walaupun terdapat hambatanhambatan yang menjadikan kegiatan tidak intensif sebagaimana mestinya. Taman baca masyarakat merupakan sarana pendidikan di luar sekolah yang bersifat fleksibel dalam memenuhi kebutuhan penggunanya dari 
berbagai lapisan. Taman bacaan masyarakat menjadi salah satu penunjang pendidikan nonformal di luar sekolah yang memiliki tujuan untuk mencerdaskan kehidupan bangsa dalam memberikan pendidikan bagi masyarakat yang belum bisa mengemban pendidikan formal. Fungsi pendidikan nonformal tercantum dalam Undang-undang Nomor 20 Tahun 2003 Tentang Sistem Pendidikan Nasional Pasal 25 Ayat 1, disebutkan bahwa pendidikan nonformal memiliki fungsi sebagai pengganti, penambah dan pelengkap sarana dan fasilitas pendidikan formal dalam mendukung pendidikan sepanjang hayat (Irawati, 2015).

Penelitian ini akan mengkaji bagaimana peran Taman Baca Bintang Kecil sebagai sarana pendidikan nonformal yang menjadi penunjang pendidikan di kala pandemi Covid-19 maupun sebelum dan setelahnya. Peneliti juga mengkaji layanan-layanan Taman Baca Bintang Kecil yang berkaitan dengan layanan perpustakaan pada umumnya. Taman bacaan masyarakat memang bagian dari pelaksanaan perpustakaan itu sendiri, namun Taman Bacaan Bintang Kecil merupakan taman bacaan masyarakat yang didirikan atas kepentingan pribadi masyarakat Desa Batu Palano sendiri, tanpa adanya campur tangan dari pengelola perpustakaan setempat maupun latar belakang dari pendirinya yang bukan seorang pustakawan. Ini menjadi kertertarikan tersendiri bagaimana layanan yang disajikan Taman Bintang Kecil cukup kompleks dengan layanan-layanan perpustakaan.

\section{TINJAUAN PUSTAKA}

\section{- Perpustakaan Umum}

Sebelum membahas pokok
permasalahan penelitian ini, ada baiknya memahami terlebih dahulu dasar literatur dari kajian yang akan dibahas agar sejalan dengan rumusan masalah yang dikaji. Literatur yang akan dibahas terlebih dahulu yaitu perpustakaan umum. Perpustakaan umum merupakan perpustakaan yang tugasnya mengumpulkan, mengelola, menyimpan, mengatur serta menyajikan sumber informasi yang dibutuhkan untuk masyarakat umum. Perpustakaan umum hadir untuk memberikan pelayanan kepada masyarakat umum secara setara tanpa memandang tingkat sosial masyarakat yang berasal dari latar belakang apapun. Sehingga koleksi-koleksi yang disediakan oleh perpustakaan umum memiliki beragam topik dan pembahasan sesuai dengan minat dan kebutuhan akan informasi dari penggunanya (Zahara, 2004). Perpustakaan bisa menjadi salah satu pilihan dari banyaknya pilihan tempat dimana masyarakat bisa mendapatkan informasi dan pengetahuan secara gratis. Kualitas sumber informasi yang diberikan oleh perpustakaan juga tidak kalah jika dibandingkan dengan lembaga informasi yang lain. Perpustakaan sendiri bukanlah hal yang asing lagi di mata masyarakat karena telah hadir di mana-mana hingga kepelosok daerah, dari keberadaannya yang berupa bangunan hingga perpustakaan keliling (Basa, 2008).

Fungsi perpustakaan umum pun disesuaikan dengan masyarakat yang beragam. Diantaranya adalah perpustakaan umum berfungsi sebagai pusat informasi yang menyediakan segala topik dan bahasan yang diminati dan dibutuhkan pengguna perpustakaan. Perpustakaan umum sebagai pelestari kebudayaan yang menyimpan dan menyediakan karya-karya tentang kebudayaan di masa lalu dan bisa menjadi wadah pengembangan kebudayaan di masa depan. Perpustakaan sebagai sarana pendidikan, ini merupakan fungsi utama yang secara tidak langsung sebagai wadah mencerdaskan kehidupan bangsa dengan pendidikan di luar sekolah dan universitas, sebagai pusat informasi untuk kebutuhan penelitian serta sarana pendidikan bagi mereka yang belum bisa mengemban pendidikan secara formal. Perpustakaan berfungsi sebagai sarana rekreasi dan hiburan dengan menyediakan bahanbahan bacaan yang ringan dan menghibur, bangunan dan fasilitas perpustakaan pun dirancang sedemikian rupa agar pengguna bisa menikmati waktu luang dan waktu konsentrasinya di perpustakaan (Zahara, 2004). Kehadiran perpustakaan di hampir seluruh daerah pemukiman masyarakat, terutama daerah yang sangat membutuhkan sarana untuk mencari informasi dan pengetahuan, menjadi harapan yang besar atas 
tujuan perpustakaan sendiri yang berusaha menjadi wadah dalam mencerdaskan kehidupan bangsa. Di samping untuk meningkatkan kecerdasan masyarakat, perpustakaan juga berusaha memperbaiki mutu kehidupan masyarakat yang membutuhkan. Tidaklah cukup hanya sarana sekolah formal yang menjadi satu-satunya hal efektif dalam proses pembelajaran dan mengemban ilmu pengetahuan, karena sekolah yang ada hanya untuk menampung anak-anak usia sekolah. Perpustakaan dibangun untuk semua kalangan usia, tingkatan pendidikan dan profesi. Semua dianggap pengguna yang setara dalam mengakses perpustakaan, sama seperti perlakuan setiap masyarakat dalam hukum. Ketertinggalan pendidikan suatu daerah dan mayoritas masyarakatnya disebabkan oleh beberapa faktor yang tidak bisa diraih semudah daerah lainnya. Sudah menjadi tugas dalam melayani masyarakat, perpustakaan bertindak untuk mengatasi ketertinggalan tersebut dimulai dari meningkatkan kecerdasan dan pengetahuan masyarakat. Dengan meningkatnya pengetahuan dan kecerdasan masyarakat, semakin meluas juga pandangan masyarakat dalam mengambil keputusan dan menghadapi masalah di hidupnya (Basa, 2008).

Perpustakaan sendiri juga memiliki unsur-unsur yang menjadikannya hadir di kehidupan masyarakat. Unsur-unsur tersebut ialah unsur tujuan yang ingin dicapai oleh perpustakaan yang berfokus pada kebutuhan pengguna, unsur koleksi bahan pustaka yang berisi informasi, pengetahuan, data, fakta, ide dan hal lainnya baik yang tercetak maupun non cetak, unsur bangunan dan fasilitasnya, unsur sistem yang mengaturnya, unsur organisasi dan tata kerja dalam pembagian tugasnya, unsur tenaga dan sumber daya manusia yang memiliki pendidikan dan keterampilan khusus di bidang perpustakaan, dan unsur yang terakhir ada masyarakat yang dilayaninya. Unsur-unsur ini merupakan satu kesatuan yang sulit dipisahkan dari perpustakaan dalam penyelenggaraannya, namun dari ketujuh unsur yang telah dipaparkan sebelumnya yang paling penting adalah unsur bahan pustaka dan unsur masyarakat yang dilayani (Zahara, 2004). Kemudian tingkat, nilai, dan public significant pada informasi merupakan tiga konsep yang harus bisa dipahami pustakawan agar sistem pelayanan perpustakaan bisa berfungsi secara efektif. Perpustakaan umum mengemban misi pelayanan informasi berskala mikro dan makro. Terdapat informasi dari atas ke bawah dan informasi yang bergerak disekitar lingkup bidang tertentu yang banyak dikelola oleh perpustakaan umum (Yusup, 2019).

\section{- Layanan Perpustakaan}

Layanan perpustakaan merupakan inti dari tugas perpustakaan itu sendiri dalam menghadapi kebutuhan penggunanya. Menurut Adhiarya, dkk (2013) kegiatan layanan perpustakaan adalah memberikan pelayanan kebutuhan informasi pengguna. Dimana pengguna perpustakaan mengharapkan pelayanan yang berkualitas dan menjadi kepuasan pengguna dalam memenuhi kebutuhan informasi. Kemudian Kotler dalam Adhiarya, dkk (2013) menjelaskan konsep dari layanan yaitu "a service any act or performance that one party can offer to another that is essentially intangible and does not result in the ownership of anything, its production may or may no be to a physical product". Artinya pelayanan merupakan setiap kegiatan yang ditawarkan oleh satu pihak kepada pihak lain, pada dasarnya layanan tidak berwujud pada kepemilikan siapapun. Produksinya dikaitkan dengan produk berupa fisik. Layanan perpustakaan berfungsi sebagai penghubung antara koleksi perpustakaan dengan pengguna yang membutuhkannya, berguna untuk mengoptimalisasikan pemanfaatan sumbersumber informasi yang ada. Layanan perpustakaan harus didasarkan pada kebutuhan penggunanya, karena pengguna perpustakaan merupakan salah satu faktor terpenting dalam perkembangan dan kebijakan di dalam lingkungan perpustakaan itu sendiri. Idealnya, layanan perpustakaan harus selalu mengalami perubahan yang lebih baik agar lebih menarik pengunjung, ramah dan efisien (Wati, 2016).

Semua bentuk layanan yang disediakan perpustakaan kepada penggunanya bersifat layanan jasa, karena perpustakaan tidak memberikan suatu produk berupa barang yang 
secara langsung bisa digunakan masyarakat. Jasa yang diberikan pun jasa sosial, dimana perpustakaan tidak mencari keuntungan komersial dan tidak akan meminta imbalan material apapun termasuk uang kepada penggunanya. Hanya saja jika ada pengguna meminta data atau informasi, perpustakaan meminta biaya perjalanannya, bukan membayar jasa pustakawannya. Maksudnya disini, misalkan jika pengguna memerlukan data yang harus difotokopi ditempat, pengguna hanya perlu membayar penggunaan fotokopi saja, jasa pustakawan yang membantunya tidak perlu dibayar. Perpustakaan hanya sebagai penyedia sumber informasi bagi siapapun yang membutuhkannya (Yusup, 2019).

\section{- Perpustakaan Umum di Pedesaan}

Jenis-jenis perpustakaan umum banyak sekali cabangnya, seperti Perpustakaan Desa yang perannya cukup penting untuk menjangkau masyarakat secara lebih intensif. Perpustakaan desa merupakan kelompok perpustakaan umum juga yang dimana keberadaan dan pengelolaannya dilakukan oleh masyarakat desa setempat. Perpustakaan kini bisa lebih dikenal dan dimanfaatkan oleh masyarakat secara rutin, berkat dukungan dan pembangunan dari pemerintah dengan mendirikan perpustakaan hingga pelosokpelosok pedesaan. Usaha dari perpustakaan sendiri pun tidak terlepas dari motivasi untuk memperkenalkan kepada masyarakat manfaat akan hadirnya perpustakaan dalam hal apapun. Peran perpustakaan desa sendiri sebagai media pembangunan sumber daya manusia di pedesaan yang berupaya mencerdaskan kehidupan masyarakat desa (Yusup, 2019; Zahara, 2004).

Dalam Instruksi Menteri Dalam Negeri Republik Indonesia Nomor 28 Tahun 1984 Tentang Pelaksanaan Penyelenggaraan Perpustakaan Desa atau Kelurahan, maka tujuan dibangunnya perpustakaan desa yaitu, (1) Untuk mencerdaskan kehidupan masyarakat desa atau kelurahan dengan mendampingi untuk menciptakan daya kreasi, prakarsa, dan swadaya masyarakat desa guna meningkatkan taraf hidup dan kesejahteraannya; (2) Sebagai penyedia berbagai kebutuhan untuk pencerahan pengambilan keputusan, sumber informasi, data sekunder dan pengetahuan ilmiah; (3) Membantu kegiatan pada bidang pendidikan masyarakat dan serta kebudayaan, baik secara individu, kelompok maupun suatu golongan atau organisasi; (4) Dapat memberikan semangat dan hiburan yang positif dalam halhal yang bersifat membangun dalam waktu luangnya; (5) Menjadi pendorong, penggairah, pemelihara dan pemberi semangat membaca dan belajar kepada masyarakat; (6) Dapat membekali masyarakat dengan berbagai ilmu dan pengetahuan serta pengalaman kepada masyarakat dalam bidang apapun. Semua tujuan tersebut memiliki harapan dalam mencapai pembangunan desa yang lebih baik dalam jangka panjang. Hal ini mengacu pada pelaksanaan pembangunan jangka panjang yang sudah direncanakan pemerintah dalam menitikberatkan kepada peningkatan kualitas sumber daya manusia (Yusup, 2019).

\section{- Taman Bacaan Masyarakat}

Selain perpustakaan desa hadir di lingkungan masyarakat, terdapat penyedia layanan informasi juga seperti perpustakaan secara sederhana, yaitu Taman Bacaan Masyarakat. Biasanya taman bacaan masyarakat ini merupakan program perpustakaan desa dalam menjangkau daerahdaerah yang cukup sulit didatangi. Ada pula taman bacaan masyarakat yang berdiri secara mandiri oleh pribadi yang memang ingin mengabdi kepada masyarakat ataupun dibangun bersama-sama atas kebutuhan masyarakat itu sendiri. Jika taman bacaan bersangkutan ingin menambah koleksi buku, bisa mengajukan ke pemerintah maupun membuka layanan donasi dari masyarakat. Hadirnya taman bacaan masyarakat secara mandiri membuktikan bahwa masih banyak masyarakat yang ingin mengakses sumber informasi dan melestarikan gemar membaca dalam kehidupannya sehari-hari. Konsep taman bacaan masyarakat sebenarnya sangat mirip dengan perpustakaan pada umumnya, hanya saja sifatnya lebih sederhana dan koleksi sumber informasinya menyesuaikan dengan pengguna setempat. 
Menurut Ninis, dkk (2017), pengertian dari Taman Bacaan Masyarakat adalah sebuah forum atau wadah yang didirikan dan dikelola oleh masyarakat maupun pemerintah sebagai penyedia akses dan sarana utama dalam layanan membaca bagi masyarakat sekitar guna mewujudkan pembelajaran sepanjang hayat demi meningkatkan kualitas taraf hidup masyarakat. Dari pengertiaan ini sangat mirip fungsi dan tujuan dari taman bacaan masyarakat terhadap perpustakaan. Secara implementasi sebagai penyelenggara sumber informasi, taman bacaan masyarakat walaupun pengunjungnya jauh lebih sedikit dibandingkan perpustakaan, akan tetapi pengurus taman bacaan masyarakat dengan anggotanya sangat akrab dan memberikan timbal balik yang positif, sehingga terlihat seperti kekeluargaan dalam merangkul anggotanya. Membangun kegemaran membaca perlu dukungan lebih dari lingkungan yang memiliki minat yang sama, sehingga satu sama lain bisa saling berdiskusi dan bertukar pendapat. Namun untuk situasi saat ini, kegiatan menarik antara perpustakaan dan taman bacaan masyarakat harus ditunda sampai waktu yang belum bisa dipastikan.

Taman Bacaan Masyarakat menurut Kementerian Pendidikan dan Kebudayaan (2015) dalam Yulianto dan Irhandayaningsih (2019) memiliki 5 tujuan saat didirikan, meliputi: (1) Meningkatkan kemampuan keberaksaraan dan keterampilan membaca masyarakat; (2) Menumbuhkan dan mengembangkan minat dan gemar membaca masyarakat; (3) Membangun masyarakat yang gemar belajar; (4) Menjadi pendorong dalam mewujudkan masyarakat pembelajar sepanjang hayat; (5) Membantu mewujudkan kualitas dan kemandirian masyarakat dalam berpengetahuan, berketerampilan, berbudaya yang maju dan beradab baik. Kemudian peran taman bacaan masyarakat di lingkungan menurut Direktorat Pendidikan Masyarakat (2006) dalam Yuliyanto dan Irhandayaningsih (2019) adalah, (1) sebagai media atau penghubung yang menjembatani antara sumber informasi dan ilmu pengetahuan, (2) sebagai lembaga yang mampu membangun minat baca masyarakat dengan menghadirkan koleksi-koleksi yang sesuai dengan keinginan dan kebutuhan masyarakat, (3) sebagai fasilitator yang aktif dalam memotivasi masyarakat yang ingin mencari, memanfaatkan dan mengembangkan ilmu pengetahuan (4) sebagai agen perubahan, pengembangan dan agen kebudayaan yang berada di sekitar masyarakat, dan (5) sebagai lembaga pendidikan nonformal bagi masyarakat, dimana masyarakat dapat belajar secara mandiri dalam melakukan penelitian maupun seluruh kegiatan belajar lainnya.

\section{- Coronavirus Disease 2019 (Covid-19)}

Pada awal tahun sampai dengan akhir tahun 2020, seluruh dunia disibukkan dengan fenomena mewabahnya sebuah virus yang menjangkit sistem pernapasan dan paru-paru (pneumonia) banyak orang, kemudian virus ini menyebar dengan sangat cepat ke lebih dari 65 sampai 190 negara dan teritori karena sifat virusnya yang sangat mudah ditularkan dari satu orang ke banyak orang lainnya. Virus ini merupakan golongan coronavirus jenis baru (SARS-CoV-2) dan penyakit ini bernama Coronavirus disease 2019 (Covid-19). Covid-19 berawal dari kota Wuhan, Provinsi Hubei, China yang ditemukan pada akhir Desember tahun 2019 (Perhimpunan Dokter Paru Indonesia, 2020; Susilo et al., 2020; WHO, 2020b; Yuliana, 2020). WHO juga menetapkan fenomena Covid-19 ini sebagai pandemic karena perkembangan Covid-19 yang sangat cepat dan menimpa seluruh masyarakat dunia secara serentak dalam skala global. Hingga saat penelitian ini ditulis, pada tanggal 27 November 2020 angka kasus Covid-19 dunia menembus hingga 60,5 juta kasus dengan angka kematian mencapai 1,4 juta jiwa (WHO, 2020a).

Di Indonesia sendiri, awal kasus Covid19 terjadi pada tanggal 2 Maret 2020 yang diumumkan oleh Menteri Kesehatan, Terawan Agus Putranto bahwa telah terjangkitnya dua orang Warga Negara Indonesia yang berasal dari Depok dan pada saat diumumkan, kedua pasien sudah dirawat secara intensif di Rumah Sakit Penyakit Intensif Prof. Dr. Sulianti Saroso, Jakarta Utara (Pakpahan \& Fitriani, 2020). Kasus Covid-19 di Indonesia sendiri telah mencapai angka sebanyak 522,581 kasus dengan angka kematian 16,521 jiwa. Ibu Kota Jakarta menjadi 
kasus penularan tertinggi se Indonesia, yaitu 132,961 kasus. Data ini diupdate pada tanggal 27 November 2020 (Kompas.com, 2020).

Gejala umum dari terjangkitnya Covid19 ini yaitu dimulai dari demam, kelelahan, batuk yang tidak berdahak dan sesak nafas. Gejala lainnya seperti hidung menjadi tersumbat, sakit kepala, sakit tenggorokan, diare, kehilangan kemampuan indra dalam mengecap dan mencium bau. Orang-orang yang berusia lanjut dan memiliki penyakit lain beresiko sangat tinggi dijangkiti oleh Covid-19 ini. Proses penularan dari Covid-19 terjadi melalui kontak manusia yang telah terjangkit Covid-19 yang kemudian ia batuk atau bersin kemudian air batuk atau bersin (droplets) tadi terhirup oleh manusia lainnya tanpa adanya perlindungan yang menutupi mulut, hidung dan mata. Karena proses penularannya yang sangat mudah menyerang, WHO dan pakar kesehatan lainnya menyarankan setiap orang untuk memakai masker 3 lapis, mencuci tangan secara berkala setelah memegang sesuatu dari tempat umum, serta menjaga jarak (physical distancing) setidaknya 1,5 meter dari orang lain (prinsip 3M) jika sedang berada di luar rumah. Apabila seseorang telah merasakan gejalagejala yang telah disebutkan tadi, sebelum bertambah parah, disarankan untuk tidak melakukan kontak sama sekali dengan orang lain termasuk keluarga selama 14 hari dan menjaga pola makan, berolahraga serta meningkatkan imun tubuh dengan mengonsumsi vitamin (Handayani, D., 2019).

Kasus mengenai Covid-19 terus terjadi peningkatan setiap harinya dan telah memakan banyak korban meskipun tingkat kematian manusia oleh virus ini sangat rendah dibandingkan dengan virus lainnya, namun tingkat penyebarannya sangat tinggi dan virus yang selalu bermutasi menjadikannya cukup sulit untuk dihentikan. Salah satu cara menghentikan perkembangan dari Covid-19 ini dengan membatasi aktivitas di ruang yang dipenuhi oleh banyak orang, seperti pasar, sekolah, kantor, stasiun, mal, dan tempat publik lainnya yang banyak kerumunan, sehingga ditetapkan pemerintah Indonesia dengan Pembatasan Sosial Berskala Besar (PSBB). Oleh karena itu, pemerintahan di seluruh dunia mengharuskan menutup akses fasilitas publik sementara dan membatasi pengunjungnya serta membuat kebijakan dan peraturan baru mengenai Covid-19, termasuk Indonesia agar angka kasus persebaran Covid-19 ini bisa ditekan. Pada kenyataannya karena merebaknya virus ini yang mengharuskan sektor utama masyarakat harus dihentikan, menjadikan efek domino kepada sektor-sektor lainnya sehingga kegiatan menjadi terganggu bahkan diambang kehancuran. Semua masyarakat perlu memutar otak dan berfikir keras untuk bertahan di masa pandemi Covid19 saat ini, termasuk perpustakaan dan taman bacaan masyarakat yang merupakan fasilitas publik dalam layanan jasa penyedia informasi.

\section{METODE PENELITIAN}

Penelitian berdasarkan pada penelitian kualitatif yang bersifat deskriptif. Dalam memperoleh data dan sumber yang dibutuhkan, terdapat tiga cara dalam perolehan sumber informasi atau data yang dibutuhkan pada penelitian ini, diantaranya: (1) Wawancara online melalui whatsapp. Dalam mematuhi protokol kesehatan, wawancara dilakukan secara online melalui whatsapp. Wawancara diperlukan dalam penelitian ini guna memperoleh informasi lebih detail dari narasumber. Dengan melakukan wawancara, informasi yang diperlukan bisa dikembangkan kualitasnya daripada menggunakan metode lain serta dapat bertanya informasi tambahan yang sebelumnya tidak bisa didapatkan dari sumber informasi yang sudah tertera (Basa, 2008). (2) Kemudian melakukan observasi secara online dari laman media sosial Taman Baca Bintang Kecil. Observasi yang dilaksanakan bukan menelusuri tempat, melainkan menelusuri media sosial Taman Baca Bintang Kecil, baik di Instagram, Facebook maupun Youtube. Dikarenakan keadaan pandemi Covid-19, turun langsung ke lapangan memiliki banyak resiko. Sehingga dalam mengumpulkan informasi, selain mewawancarai pemilik Taman Baca Bintang Kecil, penelusuran media sosial juga membantu untuk memberikan informasi tambahan dan dokumentasi terkait Taman Baca Bintang Kecil. 
(3) Terakhir pengumpulan data dengan melakukan studi literatur dalam pengembangan analisisnya. Studi literatur diperlukan karena memerlukan sumber yang valid dalam menganalisis dan mencari keterkaitan antara hasil penelitian dengan studi yang sesuai sehingga nantinya akan melahirkan kesimpulan-kesimpulan dari analisanya.

Penelitian dilaksanakan selama satu bulan mulai dari awal November hingga akhir November, dengan objek penelitiannya adalah Taman Baca Bintang Kecil yang berlokasi di Jorong III Bateh, Desa Batu Palano, Kecamatan Sungai Pua, Kabupaten Agam, Sumatera Barat dengan subjek penelitiannya adalah menganalisa layanan yang dilaksanakan oleh Taman Baca Bintang Kecil terhadap layanan perpustakaan di masa pandemi Covid-19 ini. Waktu penelitian dengan mengambil informasi melalui wawancara narasumber yaitu pendiri dari Taman Baca Bintang kecil sekitar pukul 10.00 sampai 11.00 pagi melalui whatsapp. Penelitian ini dianalisa dari hubungan layanan kegiatan Taman Baca Bintang Kecil dengan layanan perpustakaan, apakah memiliki kesamaan layanan walaupun memiliki title yang berbeda serta bagaimana Taman Baca Bintang Kecil bertahan dalam situasi pandemi Covid-19. Dari pembahasan penelitian ini nanti akan diungkap bagaimana hubungan antar keduanya tersebut.

\section{PEMBAHASAN}

Sampai saat ini pandemi Covid-19 selalu menjadi topik perbincangan utama yang dibahas oleh seluruh dunia dalam berbagai bidang, hingga pemerintahan diseluruh dunia turut membuat peraturan baru yang menyesuaikan dengan keadaan Covid-19 untuk menekan angka kasus yang terus memakan korban setiap harinya. Bagi daerah yang tidak mendapatkan cukup kemudahan dalam mengakses informasi dan fasilitas terkait Covid19 , namun tetap terkena imbas dengan segala peraturannya, ini perlu menjadi perhatian kita bersama untuk turut bergotong royong dalam mensosialisasikan gaya hidup yang sehat dan tetap menjaga kebersihan agar imunitas pada diri kita terbentengi dengan baik dan bisa bertahan dengan kondisi lingkungan yang sudah cukup tercemar dengan virus corona ini.

Taman Baca Bintang Kecil yang baru berjalan satu tahun sejak berdiri pada tanggal 1 Mei 2019 ini turut merasakan hambatan dari pandemi Covid-19. Pengunjung yang mayoritas anak-anak dengan usia 5 sampai 15 tahun sebelum adanya pandemi Covid-19 bisa berkunjung sampai 25 anak setiap harinya. Namun sejak pandemi Covid-19, berkurang sangat dratis. Taman Baca Bintang Kecil juga secara resmi mengurangi aktivitas yang biasanya dilakukan rutin setiap hari. Kegiatan Taman Baca Bintang Kecil sebelum pandemi Covid-19, terdapat beberapa kegiatan diantaranya: (1) Senin Mewarnai, (2) Kamis Story Telling, (3) Sabtu Menggambar, dan (4) Minggu ada English Funday, Minggu Bermain dan Minggu Kreasi. Sejak pandemi Covid-19, aktivitas yang terlalu banyak kontak fisik diberhentikan sementara, yaitu kegiatan Minggu Bermain dan Minggu Kreasi.

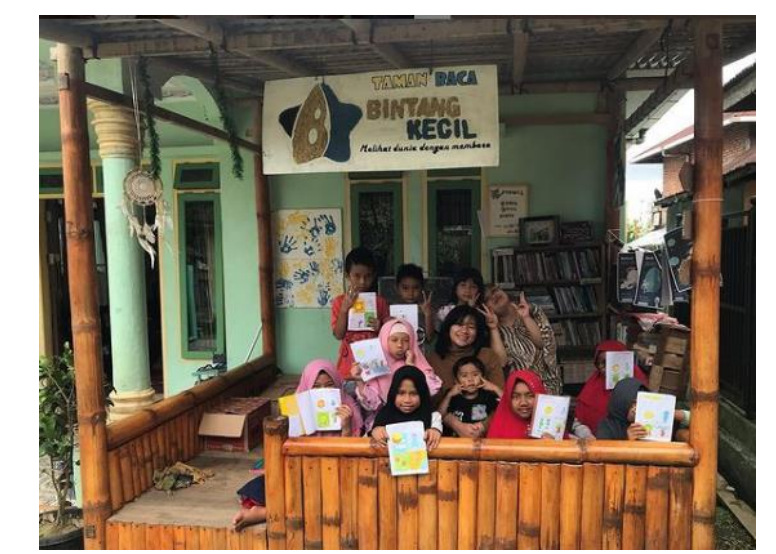

Gambar 1. Kegiatan Minggu English Funday di Taman Baca Bintang Kecil

Sumber: http://instagram.com/tamanbaca_bintangkecil

Taman Baca Bintang Kecil belum bisa membuat program-program baru untuk menyesuaikan keadaan di pandemi Covid-19. Tidak bisanya tatap muka dan kontak langsung dengan banyak orang sulit membuat kegiatan baru. Membuat program berbasis online pun tidak bisa dilaksanakan karena di Desa Batu Palano, pengunjung yang mayoritas anak-anak tidak mempunyai gadget. Yang dilakukan Taman Baca Bintang Kecil hanya bisa meminjamkan koleksi-koleksinya untuk dipinjam dan dibawa pulang yang kemudian 
dibaca di rumah. Namun untuk pengurus Taman Baca Bintang Kecil, kegiatan online bisa dilakukan dalam rangka menambah wawasan mengenai kegiatan seputar literasi, berkolaborasi dan berdiskusi dengan taman bacaan masyarakat lainnya maupun dengan platform-platform pengembangan diri dan skill.

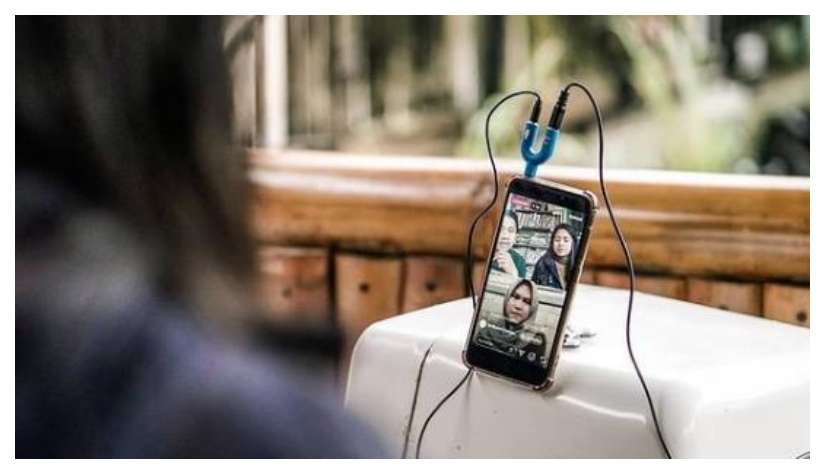

Gambar 2. Pendiri Taman Baca Bintang Kecil sedang diskusi dengan TBM lainnya

Sumber: http://instagram.com/tamanbaca_bintangkecil

Jika kita amati lebih lanjut sebenarnya pelaksanaan kepengurusan Taman Baca Bintang kecil ini sangat mengimplimentasikan peran pustakawan dalam melayani pengguna didalamnya, sesuai yang tertera pada Peraturan Kepala Perpustakaan Nasional Republik Indonesia Nomor 11 Tahun 2015 Tentang Petunjuk Teknis Jabatan Fungsional Pustakawan dan Angka Kreditnya (2015). Pada rincian Bab 3 dijelaskan beberapa kegiatan yang dapat dimanfaatkan pengguna perpustakaan dalam mengakses informasi perpustakaan yang sejalan dengan kegiatan yang telah dilaksanakan oleh Taman Baca Bintang Kecil.

Pertama, melakukan layanan peminjaman dan pengembalian koleksi. Taman Baca Bintang Kecil memberlakukan layanan ini sejak pandemi Covid-19 karena keadaan yang tidak memungkinkan untuk membaca dan mengakses koleksi di tempat, sehingga Taman Baca Bintang Kecil mengizinkan masyakarat meminjam dan mengakses koleksi untuk dibawa ke rumah yang pada awalnya seluruh koleksi hanya bisa dibaca dan diakses di tempat.

Kedua, menyediakan koleksi di tempat. Layanan ini merupakan layanan utama Taman Baca Bintang Kecil sejak awal berdiri dalam memberikan informasi kepada penggunanya. Koleksi-koleksi disediakan sesuai dengan kebutuhan penggunanya yang dimana mayoritas adalah anak-anak, sehingga koleksi yang disediakan lebih difokuskan untuk anakanak sekitar umur 5-15 tahun.

Ketiga, melakukan layanan orientasi perpustakaan yang menyangkut pengenalan dasar kepada pengguna baru, seperti struktur organisasi, lokasi perpustakaan, peraturan dan tata tertib, jenis layanan, serta hal lainnya yang menyangkut pelaksanaan perpustakaan secara sederhana. Pengenalan seperti ini juga turut dilakukan oleh Taman Baca Bintang Kecil berupa pengenalan pengurus-pengurusnya yang akan anak-anak Batu Palano anggap sebagai guru atau tutor, letak koleksi-koleksi yang disediakan dan bagaimana menyimpannya kembali, tata tertib dan peraturan saat berada di Taman Baca Bintang Kecil, dan menunjukkan bagaimana cara menelusuri koleksi yang dibutuhkan, biasanya sudah dikelompokkan sesuai pemahaman pengguna sehingga jika dibutuhkan kembali akan cepat ditemukan dan yang terakhir adalah ruang baca yang nyaman.

Keempat, melakukan layanan story telling, layanan ini ada disediakan oleh pustakawan di perpustakaan dengan tujuan untuk menyampaikan suatu cerita kepada pengguna jika dibutuhkan baik dalam bentuk kata-kata, maupun disandingi dengan audio dan visual seperti foto, slide, video, dan rekaman suara yang didasarkan pada suatu topik dalam buku bacaan agar menumbuhkan minat baca dan pengetahuan penggunanya. Taman Baca Bintang Kecil menjadikan layanan ini sebagai kegiatan rutin setiap minggu di hari kamis, biasanya akan dibuka dahulu topik cerita oleh pengurusnya, kemudian anak-anak Batu Palano dapat menanggapi ceritanya ataupun hal yang sebaliknya.

Terakhir ada beberapa layanan lainnya yang ada pada Taman Baca Bintang Kecil yang secara sederhana sangat sesuai dengan layanan di perpustakaan pada umumnya. Layanan tersebut meliputi layanan penyebaran informasi terbaru, seperti sosialisasi mengenai keadaan pandemi Covid-19 saat ini dalam melakukan aktivitas 3M (Memakai masker, Menjaga jarak, dan Mencuci tangan) untuk menjaga kebersihan dan kesehatan, sosialisasi 
menjaga kebersihan dengan membuang sampah pada tempatnya atau melakukan kegiatan daur ulang membuat kerajinan untuk menyelamatkan bumi dari sampah, dan sosialisasi lainnya yang sebenarnya sangat mudah ditanamkan kebiasaan seperti itu untuk anak-anak.

Taman Baca Bintang Kecil yang memiliki tag line atau tujuan utama "Melihat Dunia Dengan Membaca" memiliki latar belakang yang cukup memotivasi karena letak Desa Batu Palano yang berada di kaki Gunung Marapi masih banyak keterbatasan dalam mengakses pendidikan dan teknologi. Walaupun adanya keterbatasan tersebut, Taman Baca Bintang Kecil memiliki solusi agar tetap bisa mengakses informasi dan pengetahuan secara global dengan membaca. Tidak adanya fasilitas toko buku maupun perpustakaan daerah terdekat, Taman Baca Bintang Kecil hadir untuk memfasilitasi dengan koleksi-koleksinya menjadi media edukasi untuk anak-anak Desa Batu Palano.

\section{KESIMPULAN}

Hadirnya taman bacaan di kalangan masyarakat merupakan implementasi perpustakaan sesungguhnya yang mengabadikan kegiatannya untuk kesejahteraan masyarakat terkait perkembangan literasi. Konsep taman bacaan yang lebih bersifat kekeluargaan dan peraturan yang dimusyawarahkan bersama-sama, menjadi bukti nyata bahwa tujuan mulia perpustakaan sesungguhnya ada pada pelaksanaan taman bacaan masyarakat yang secara suka rela berdiri, berkeliling dan mencari referensi serta sumber koleksi untuk memenuhi kebutuhan informasi dan pengetahuan terhadap penggunanya dengan kontak langsung dan pendekatan secara kekeluargaan.

Berdirinya Taman Baca Bintang Kecil di Desa Batu Palano bisa menjadi langkah awal untuk meningkatkan koleksinya sehingga di masa yang akan datang bisa berkembang menjadi perpustakaan desa yang dimana tidak hanya anak-anak sekolah saja yang akses informasinya diutamakan, akan tetapi bisa juga memberikan sumber-sumber koleksi kepada Masyarakat Desa Batu Palano Lainnya. Mayoritas masyarakat yang bertani dan beternak bisa menghadirkan koleksi-koleksi yang berhubungan dengan pertanian dan peternakan, agar para petani dan peternak Desa Batu Palano bisa mengaplikasikan informasi yang didapatkan dari sumber koleksi yang mereka baca.

\section{DAFTAR PUSTAKA}

Adhiarya, K., Setyadi, A., \& Suwarno, W. (2013). Kajian Sikap Pustakawan Dalam Meningkatkan Kualitas Layanan di Perpustakaan Fakultas Teknologi Informasi dan Komunikasi Universitas Semarang.

Basa, F. (2008). Peran pustakawan terhadap pengembangan perpustakaan keliling pada perpustakaan umum kota tangerang. Universitas Islam Negri Syarif Hidayatullah Jakarta.

Damayani, N. A., Silviana, T., Saaepudin, E., \& Budiono, A. (2017). Pengembangan Taman Bacaan Masyarakat (Tbm) di Desa Sindangkerta Kecamatan Cipatujah Kabupaten Tasikmalaya. Jurnal Aplikasi Ipteks untuk Masyarakat, 6(1), 57-61.

Direktorat Pendidikan Masyarakat, D. J. P. L. S. dan P. \&, \& Nasional, D. P. (2006). Pedoman Pengelolaan Taman Bacaan Masyarakat (TBM). Jakarta: Direktorat Pendidikan Masyarakat.

Direktur Jenderal Pendidikan Anak Usia Dini, Nonformal, dan I. dan D. P. P. M. (2015). Petunjuk Tenis Pengajuan, Penyaluran, dan Pengelolaan Bantuan Taman Bacaan Masyarakat Rintisan.

Handayani, D., et all. (2019). Penyakit Virus Corona. CPD Infection, 3(1), 9-12.

Irawati, D. (2015). Hubungan Antara Sistem Layanan Sirkulasi Dengan Kepuasan Pemustaka Taman Bacaan Masyarakat (TBM) Taman Flora Surabaya. J+Plus Unesa, 4(1). 
Kompas.com. (2020). Data Covid-19 di Indonesia. Diambil dari https://www.kompas.com/covid-19

Pakpahan, R., \& Fitriani, Y. (2020). Analisa Pemanfaatan Teknologi Informasi Dalam Pembelajaran Jarak Jauh Di Tengah Pandemi Virus Corona Covid-19. Jisamar (Journal of Information System, Applied, Managemen, Accounting and Researh), 4(2), 30-36. Diambil dari http://journal.stmikjayakarta.ac.id/index. php/jisamar

Perhimpunan Dokter Paru Indonesia. (2020). Panduan Praktik Klinis: Pneumonia 2019nCov. Jakarta: PDPI.

Perpustakaan Nasional Republik Indonesia. Petunjuk Teknis Jabatan Fungsional Pustakawan dan Angka Kreditnya. , Pub. L. No. 11 Tahun 2015 (2015).

Susilo, A., Rumende, C. M., Pitoyo, C. W., Santoso, W. D., Yulianti, M., Herikurniawan, H., ... Yunihastuti, E. (2020). Coronavirus Disease 2019: Tinjauan Literatur Terkini. Jurnal Penyakit Dalam Indonesia, 7(1), 45. https://doi.org/10.7454/jpdi.v7i1.415

Wati, L. S. S. (2016). Mengenal Layanan Perpustakaan. Diambil 15 September 2020, dari Dinas Perpustakaan dan Kearsipan Provinsi Nusa Tenggara Barat website: https://dpkp.ntbprov.go.id/beritamengenal-layanan--perpustakaan.html WHO. (2020a). WHO Coronavirus Disease (COVID-19) Dashboard. Diambil 21 November 2020, dari covid19. who.int

WHO. (2020b). WHO Director-General's remarks at the media briefing on 2019nCov on 11 February 2020. Diambil dari https://www.who.int/dg/speeches/detail /who-director-generals-remarks-at-themedia-briefing-on-2019-ncov-on-11february-2020

Yuliana. (2020). Corona Virus Diseases (Covid19); Sebuah tinjauan literatur. Wellness and Healthy Magazine, 2(February), 124137.

https://doi.org/10.2307/j.ctvzxxb18.12

Yuliyanto, Y., \& Irhandayaningsih, A. (2019). Pemberdayaan Masyarakat Melalui Taman Baca Masyarakat ( TBM ): Studi Kasus di Desa Pledokan Kecamatan Sumowono Kabupaten Semarang. Anuva: Jurnal Kajian Budaya, Perpustakaan, dan Informasi, 3(4), 377-386. Diambil dari https://ejournal2.undip.ac.id/index.php/a nuva/article/download/6510/3379

Yusup, P. M. (2019). Ilmu Informasi, Komunikasi, dan Kepustakaan (2 ed.; R. Damayanti, Ed.). Jakarta: PT Bumi Aksara.

Zahara, Z. (2004). Konsep Dasar IImu Perpustakaan. USU digital library, 1-33. 